\title{
Fate of Nitrate In Soil Cultivated With Maize (Zea mays L.) Under Different Patterns of Irrigation Regime and Localized Compaction
}

\author{
A.M. Aggag 1
}

\begin{abstract}
The objective of this study was to evaluate the localized compaction (LC) and irrigation regime application management on maize (Zea mays $\mathrm{L}$.) growth grown in calcareous soil and nitrate leaching from a maize field and also to evaluate LEACHM model for predicting water, and nitrate spatial and temporally in the soil. Field experiment was carried out using calcareous sandy loam soil in ELBoston region, West Nile Delta, Egypt, under furrow irrigation system. Two water irrigation regimes were used: Field capacity (I-1) and Saturation (I-2) as upper limits for soil water contents. The lower limit for irrigation for both regimes is $50 \%$ of soil available water. Ammonium nitrate fertilizer was banded with four treatments of localized compaction: control without compaction (LC-1), compaction under a fertilizer band (LC-2), compaction above a fertilizer band (LC-3) and a combination of the previous two positions (LC-4). The four compaction techniques did not affect significantly the soil nitrate concentrations under F.C. irrigation treatment (I1). There were significant differences between the two irrigation regimes (I-2 and I-1) in grain yield, ear weight, ear tall, ear diameter, leaf surface area, plant height, stem diameter, leaf fresh and dry weight, plant biomass production, total dry matter and nitrate leaching losses. These differences may be due excessive $\mathrm{NO}_{3}^{-}$leaching in I2 irrigation treatment. Leaching losses of $\mathrm{NO}_{3}^{-}$of I-1 irrigation treatment decreased by $75.68 \%$ with comparison to I-2 irrigation treatment. The average leaching losses for localized compaction treatments under I-1 irrigation were $36.43,38.10,31.22$ and $31.86 \mathrm{~kg} \mathrm{ha}^{-1}$, respectively, and the corresponding losses for I-2 irrigation were $177.76,179.85,104.31$ and $103.93 \mathrm{~kg} \mathrm{ha}^{-1}$ for $\mathrm{LC}-1, \mathrm{LC}-2, \mathrm{LC}-3$, and $\mathrm{LC}-4$, respectively. The LEACHM model well predicted the concentrations of $\mathrm{NO}_{3}^{-}$ in soil profile and leachate as compared with the observed values. The ability of the model for $\mathrm{NO}_{3}^{-}$prediction was evaluated using different statically scales which proved that LEACHM model is a useful tool for optimizing and managing the application of irrigation water and $N$ fertilizer in maize field under the used experimental conditions.
\end{abstract}

Keywords: Nitrate, Leaching, Compaction, LEACHM model, Compaction Dependency, Maize

\section{INTRODUCTION}

Crop production with excessive water and fertilizers uses is no longer acceptable as an agricultural practice. Booming world population, limitation of water resources and environmental pollution concerns as well as other production related factors, impact significantly the agricultural management. Nitrogen $(\mathrm{N})$ is an essential plant nutrient but it's overusing could gradually deteriorate surface and groundwater resources. These deterioration have increased the global environmental concerns. Utilization of $\mathrm{N}$ fertilizer in a correct amount and application practice might minimize the $\mathrm{N}$ leaching that reduces the environmental deterioration (MajnooniHeris, 2014).

Maize (Zea mays L.) is a cereal crop that is cultivated widely throughout the world in a range of agro-ecological environments. Its growth is often limited by amounts of irrigation water and precipitation in arid and semi-arid regions. Maize is mostly grown under irrigation in Egypt and highly sensitive to irrigation water (Majnooni-Heris et al., 2011). The response of maize grain yield to the application of nitrogen fertilizer and irrigation water was investigated extensively (Majnooni-Heris et al., 2011 and ZandParsa et al., 2006).

Globally, nitrogen $(\mathrm{N})$ fertilizer applications are approximately 80 million tones, with half being applied in developing countries and the other half in developed countries (FAO, 1990). It has been estimated that by the year 2025 , the consumption of nitrogen fertilizer will increase from 60 to 90 percent, with two-thirds of this being applied in the developing world. This trend in fertilizer use is mostly driven by the need of developing countries to keep food supply up with population growth (Tani et al., 2004). Therefore, improvement of fertilizer use efficiency is necessary to increase crop productivity and reduce environmental pollution (Gehl et al., 2004 and 2005).

Diverting the flow of infiltrating water from the fertilizers and compacting the soil above the injected fertilizers can reduce $\mathrm{NO}_{3}^{-}$leaching. A new fertilizer application was investigated by (Baker et al., 1997). This device forms a small compacted layer of a localized compaction. The applicator is evaluated by measuring soil physical properties for the compacted layer. Sound irrigation management requires a careful balance between water inputs (rainfall and irrigation) and water outputs (crop use and evaporation) to minimize leaching losses. Thus, the nitrogen fertilizer management program and the water management

\footnotetext{
${ }^{1}$ Natural Resources and Agricultural Engineering Dept., Faculty of Agriculture-Damanhour University, Egypt Received May 12, 2016, Accepted May 30, 2016
} 
program need to be combined for an effective crop management program.

With the rapid development of computer science in recent years, simulation models are preferred to be utilized in order to investigate simultaneous the flux of water and nitrogen in the soil profile for the purpose of water and fertilizer management on farms.In this study, the LEACHM model developed by Wagenet and Hutson (1989) and Hutson (2003) was used to simulate soil water content, soil nitrate, nitrate leaching and plant nitrogen uptake. Many researchers have started to use modern computation machines to simulate plant growth, nitrogen and soil water balance in order to manage $\mathrm{N}$ and water application, in recent years. This has resulted to generation of so many computer models in various complexity levels, from very simple to complex models (Zand-Parsa et al., 2006).

The Objectives of this study, therefore, were to: (i) reduce nitrate leaching toward water resources and improve groundwater quality, through the adoption of the improved nitrogen and water management practices, (ii) evaluate the effectiveness of the localized compaction to reduce $\mathrm{NO}_{3}-\mathrm{N}$ leaching and improve its use efficiency in a maize field under different water regimes and different localized compaction, (iii) determine soil nitrate vertical distribution after crop yielding as affected by localized compaction treatments, (iv) calculate compaction dependency and yield response under different water regimes with different locations of localized compaction and (v) investigate the performance of LEACHM model to simulate nitrate leaching under different irrigation water, nitrogen fertilizer and localized compaction treatments.

\section{MATERIALS AND METHODS}

The characteristics of the used soil, set up of the experiment, data analysis and the LEACHM model are presented in the following paragraphs.

\section{Soil Characteristics}

Field experiment was carried out at El-Boston Farm Experiment Station, Faculty of Agriculture, Damanhour

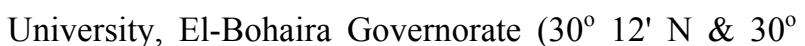
$30^{\prime} \mathrm{E}$ and altitude of $7.4 \mathrm{~m} \mathrm{ASL}$ ). The main chemical and physical properties of the soil were determined according to the methods outlined by Klute (1986 a) and the obtained results are shown in Table (1). It is clear from Table 1 that the soil is calcareous Sandy Loam. This soil represents the newly reclaimed lands in the region.

Total soil porosity and pore size distribution were calculated using the soil water characteristics curves by capillary rise equation. Five replicates from each localized compaction treatment $(5 \mathrm{~cm}$ depth) were taken to determine the bulk density using Clod Method (Hartge et al., 1985). It is obvious that the relation between soil water (soil solution) content and matric potential is a fundamental part of the characterization of the hydraulic properties of a soil. The soil water characteristics curve was measured as described by Klute (1986b) and the saturated hydraulic conductivity was measured using constant head method. Sand, silt and clay percentages were determined using hydrometer method (Klute, 1986a).

Soil nitrate was extracted with $2 \mathrm{M} \mathrm{KCl}$ solutions, and its concentration was measured using UV spectrophotometer according to Arnold et al. (1992). Total nitrogen content in plant was measured using modified microKjeldahl method according to Peack and Tracey (1956).

The source of irrigation water used in this study is El-Nubariya canal. The water has $\mathrm{pH}$ of 7.54, EC of $0.62 \mathrm{dSm}^{-1}$ and $\mathrm{NO}_{3}^{-}-\mathrm{N}$ of $1.6 \mathrm{ppm}$.

\section{Experimental design}

Field experiment was carried out in 2010 under furrow irrigation system. The experimental area was prepared using chisel plow then harrowed. No additional practices was used after soil preparation. The field area was divided into 24 squared plots (each $25 \mathrm{~m}^{2}$ ) with $1.5 \mathrm{~m}$ border between plots, to avoid the horizontal water seepage.

Table1. The main soil chemical and physical properties of the experimental soil

\begin{tabular}{|c|c|c|c|c|c|c|c|c|c|}
\hline \multirow{2}{*}{ Parameter } & \multirow{2}{*}{ unit } & \multicolumn{3}{|c|}{ Soil depth (cm) } & \multirow{2}{*}{ Parameter } & \multirow{2}{*}{ unit } & \multicolumn{3}{|c|}{ Soil depth (cm) } \\
\hline & & 0-30 & $30-60$ & $60-100$ & & & 0-30 & $30-60$ & $60-100$ \\
\hline $\mathrm{pH}_{(1: 2.5)}$ & & 8.30 & 8.20 & 8.24 & $\mathrm{CaCO}_{3}$ & $\%$ & 13.5 & 14.6 & 14.9 \\
\hline E.C.* ${ }^{*}$ & $d \mathrm{Sm}^{-1}$ & 1.40 & 1.50 & 1.64 & B. D. & $M g m^{-3}$ & 1.41 & 1.45 & 1.42 \\
\hline SAR & & 1.88 & 2.00 & 3.20 & $\mathrm{~K}_{\mathrm{s}}$ & $m d^{-1}$ & 3.60 & 3.74 & 3.68 \\
\hline O.C. & $\%$ & 0.40 & 0.16 & 0.05 & Gravel & $\%$ & 3.8 & 5.0 & 1.2 \\
\hline $\mathrm{NO}_{3}-\mathrm{N}$ & $m g \mathrm{~kg}^{-1}$ & 10.6 & 10.7 & 11.1 & Sand & $\%$ & 78.3 & 80.8 & 79.5 \\
\hline Saturation & $\mathrm{m} \mathrm{m}^{-3}$ & 0.47 & 0.45 & 0.46 & Silt & $\%$ & 10.5 & 5.9 & 6.7 \\
\hline FC & $\mathrm{m} \mathrm{m}^{-3}$ & 0.191 & 0.193 & 0.197 & Clay & $\%$ & 11.2 & 13.3 & 13.8 \\
\hline PWP & $\mathrm{m} \mathrm{m}^{-3}$ & 0.110 & 0.110 & 0.112 & Texture & & S.L.** & S.L. & S.L. \\
\hline $\mathrm{AW}$ & $\mathrm{mm} \mathrm{m}^{-1}$ & 90 & 83 & 85 & Basic I.R. & $m d^{-1}$ & 3.77 & & \\
\hline
\end{tabular}

*Soil paste extract **Sandy Loam 


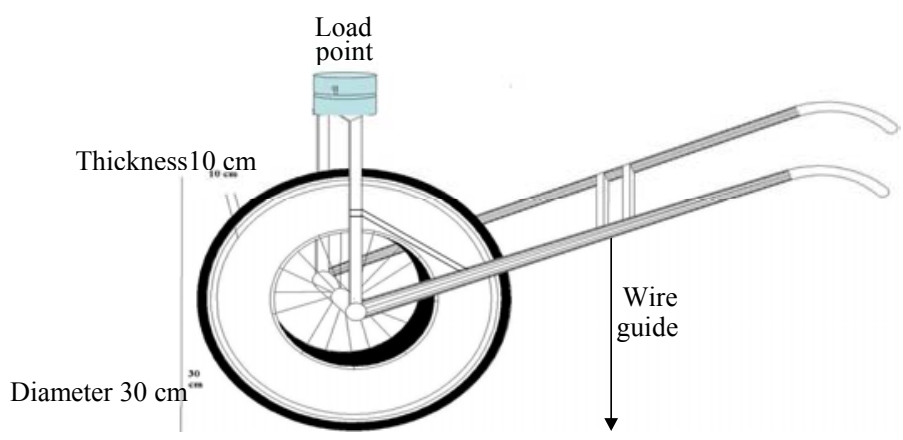

Fig. 1. The compacting wheel device used with loads

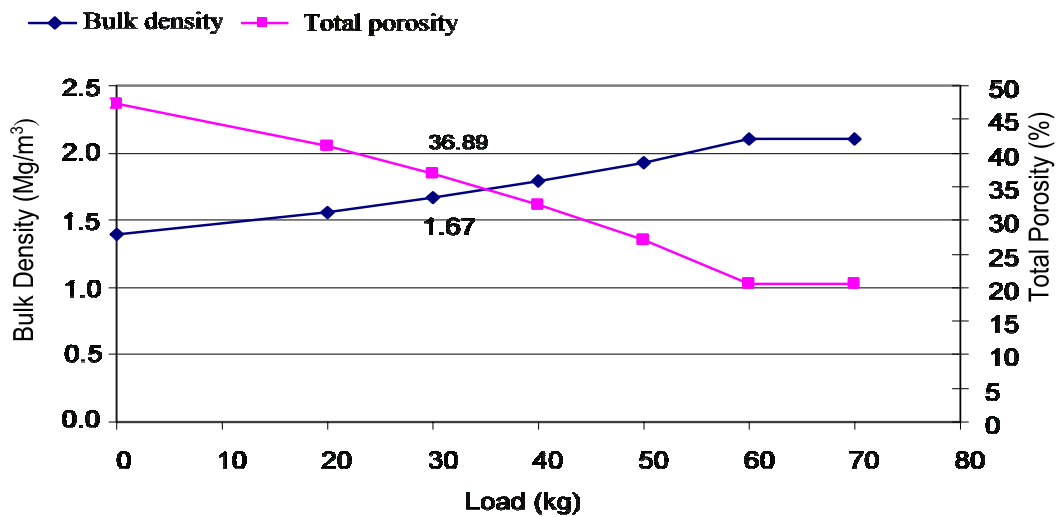

Fig. 2. The relation between exerted compaction (load, kg) and both bulk density and total porosity

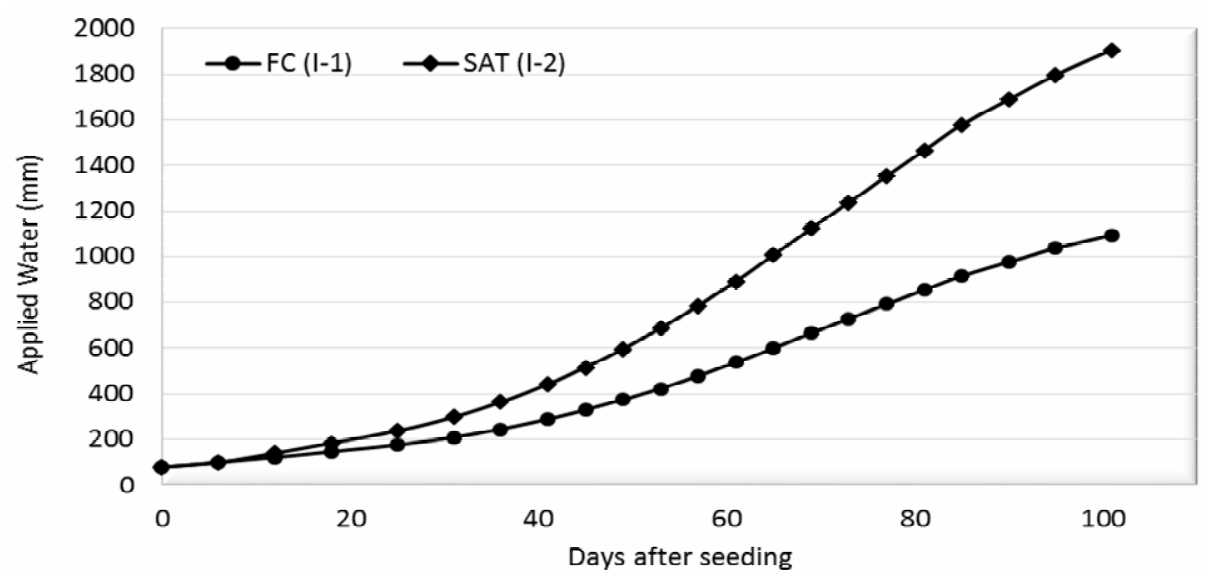

Fig. 3. Cumulative applied water to maize for the two irrigation treatments during the growing season 
The soil was cultivated with maize pioneer variety (30 kaf 8). Planting was achieved by hand in rows 60$\mathrm{cm}$ apart $\left(15 \mathrm{~cm}\right.$ between plants) on the $3^{\text {rd }}$ of May 2010. After complete seed germination, the plants were thinned to $30 \mathrm{~cm}$ between plants in the row, and one plant in each hill. Split plot statistical design was used with two water applications as the main plots; Field capacity (I-1) and up to saturation (I-2) as upper limits for soil water contents. The lower limit for irrigation for both regimes is $50 \%$ of soil available water. Nitrogen fertilizer was banded in four treatments of localized compaction (LC) as sub main plot as follows: (i) The control without compaction (LC-1), (ii) compaction beneath the fertilizer band (LC-2), (iii) compaction above the fertilizer band (LC-3), and (iv) combination of the latter two patterns (beneath and above fertilizer band) (LC-4). The nitrogen fertilizer, at a rate of $285 \mathrm{~kg}$ $\mathrm{N} \mathrm{ha}^{-1}$ as ammonium nitrate $(33.5 \% \mathrm{~N})$ was added in one dose (at planting). Also, $\mathrm{P}$ fertilizer as superphosphate $\left(\begin{array}{lll}15 \% & \mathrm{P}_{2} \mathrm{O}_{5}\end{array}\right)$ and $\mathrm{K}$ fertilizer as potassium sulfate $\left(50 \% \mathrm{~K}_{2} \mathrm{O}\right)$ were applied at sowing according to the recommended rates of MALR. Localized soil compaction treatments were executed using heavy wheel loads (Fig. 1).

The exerted compaction value was calculated using bulk density as indicator which was increased from 1.41 $\mathrm{Mg} \mathrm{m}^{-3}$ (control) to $1.67 \mathrm{Mg} \mathrm{m}^{-3}$. This was carried out by using different loads on the compacting wheel as shown in Fig. (2). For each experimental plot, the cultivated lanes were subjected to the compaction load (30 kg) which led to medium bulk density of $1.67 \mathrm{Mg}$ $\mathrm{m}^{-3}$ (Abou Arab et al., 1998; Emir, 2002 and Abdallah, 2008). It has been reported that the ability of soil for compaction is affected by soil texture, initial soil bulk density and matric potential (Peng et al., 2004).

The total amount of applied irrigation water, number of irrigations, irrigation intervals, net irrigation requirement (NIR), gross irrigation requirements (GIR), and cumulative water applied (CWA) to maize were calculated using FAO-CWR version 8 (Allen et al., 1998). The cumulative water applied is illustrated in Fig. 3 for the treatments of irrigation. When the soil water drops to $50 \%$ of the soil available water, water is applied to increase the soil water content to either field capacity (I-1) or saturation condition (I-2). Total applied water was $1904 \mathrm{~mm}$ for saturation treatment (I-2) and $1094 \mathrm{~mm}$ for field capacity treatment (I-1). The highest value of daily crop consumptive water use $\left(\mathrm{ET}_{\mathrm{C}}\right)$ was $8.3 \mathrm{~mm} \mathrm{~d}^{-1}$ which was recorded for mid-season growth stage.

Random samples of maize plant were collected from each sub-plot at harvest (15 ${ }^{\text {th }}$ of Aug. 2010) to determine plant height $(\mathrm{cm})$, number of leaves per plant, stem diameter, ear length $(\mathrm{cm}), 100$ kernel weight $(\mathrm{g})$, total fresh weight, leaf area per plant $\left(\mathrm{m}^{2}\right)$ and Total grain yield $(\mathrm{kg})$.

The obtained data were statistically analyzed using CoStat computer program for statistics (version 6.4) as split plot arrangement in randomized complete block design with three replicates.

\section{Analysis}

\section{1-Water Efficiency:}

Several terms of water uses efficiency were used (Hillel and Baker, 1998; and Schneider and Howell, 1999) as follows:

The water use efficiency (WUE) was calculated as:

WUE $=\frac{\mathrm{GW}}{\mathrm{CU}}$

The water utilization efficiency (WUTE) was calculated as:

WUTE $=\frac{G W}{A W}$

The biomass production efficiency (BPE) was calculated as:

$$
\mathrm{BPE}=\frac{\mathrm{BPW}}{\mathrm{CU}}
$$

Where:

$\mathrm{GW}$ is the grain weight $(\mathrm{kg}), \mathrm{CU}$ is the consumptive water use (mm), AW is the applied water $(\mathrm{mm})$ and the BPW is the biomass production weight $(\mathrm{kg})$

\section{2-Nitrogen Efficiency:}

Analysis of the nitrogen fertilizer efficiencies was calculated using the efficiency parameters defined by Huggins and Pan (1993) as follows:

$$
\begin{aligned}
& \text { NUE }=\frac{G_{w}}{N_{S}} \\
& \text { NUTE }=\frac{G_{w}}{N_{t}} \\
& \text { GNAE }=\frac{N_{g}}{N_{s}}
\end{aligned}
$$

Where:

NUE is nitrogen use efficiency, NUTE is the nitrogen utilization efficiency, GNAE is the grain accumulation efficiency, $G_{w}$ is the grain yield $(\mathrm{kg}), N_{g}$ is the grain nitrogen $(\mathrm{kg}), N_{s}$ is the nitrogen supply $(\mathrm{kg})$, and $N_{t}$ is the aboveground plant nitrogen $(\mathrm{kg})$.

3-Compaction dependency (CD) 
It is defined as the increasing or decreasing percentage of such a parameter due to compaction. It can be expressed as:

$$
C D=\frac{Y_{t}-Y_{c}}{Y_{c}}
$$

Where:

$Y_{t}$ is the yield of such parameter under compaction, and $\mathrm{Y}_{\mathrm{c}}$ is the yield of the parameter under noncompaction.

\section{4- Simulation Nitrate Model (LEACHM):}

The LEACHM (Leaching Estimation and Chemistry Model) was developed primarily by Wagnent and Huston (1989). The code is multipurpose that can describe matter and energy spatial and temporally. It was revisited and modified by Huston (2003). The latter version was used to simulate soil water movement and nitrate movement. LEACHM can be used to simulate the water regime, the chemistry and transport of solutes in unsaturated or partially saturated soils to a depth of about one meter. Some of the governing equations of the model are described briefly in the present study. The model efficiency for prediction was evaluated too.

Solving the following equations describe temporal and spatial variations of soil water content and inorganic solute concentration $\left(\mathrm{NO}_{3}^{-}\right)$. Assuming one-dimensional transfer in the $\mathrm{z}$ direction, the nonsteady- transfer equation of water flow can be written as

$\alpha_{1} \frac{\partial \theta}{\partial t}=-\Delta \cdot\left(q_{v} / \rho_{w}+q_{L} / \rho_{L}\right)-U(z, t)$

Where:

$\mathrm{q}_{\mathrm{v}}$ and $\mathrm{q}_{\mathrm{L}}$ are the mass fluxes of vapor and soil water, respectively $\left(\mathrm{kg} \mathrm{m}^{-2} \mathrm{~s}^{-1}\right), \theta\left(\mathrm{m}^{3} \mathrm{~m}^{-3}\right), \rho_{\mathrm{w}}$ and $\rho_{\mathrm{L}}$ are the density of pure water and soil solution, respectively, $(\mathrm{kg}$ $\left.\mathrm{m}^{-3}\right), \quad \alpha_{1}$ is storage terms for water and $\mathrm{U}$ is a sink term representing water lost per unit time by transpiration and $t$ is time $(\mathrm{s})$.

The nonsteady-state equation for $\mathrm{NO}_{3}$ transport can be written as

$\frac{\partial(C \theta)}{\partial t}=-\Delta \cdot\left(\frac{n_{c}}{\rho_{L}}\right) \pm \phi$

Where:

$\mathrm{n}_{\mathrm{c}}$ is the net flux of solute $\left(\mathrm{mol} \mathrm{m} \mathrm{m}^{-2} \mathrm{~s}^{-1}\right), \phi$ indicates sources and/or sink term for $\mathrm{NO}_{3}$ solute and $\mathrm{C}$ nitrate concentration in soil solution $\left(\mathrm{mol} \mathrm{kg}^{-1}\right)$.

Solving the above equations of transient water and nitrate flow requires the initial and boundary conditions. Additionally, the transport parameters of water and solute are needed.

The initial conditions associated with Eqs. (8) and (9) are given by the following: $\theta_{(\mathrm{z}, 0)}=\theta_{\mathrm{i}}, \mathrm{C}_{(\mathrm{z}, 0)}=\mathrm{C}_{\mathrm{i}}, \quad(0<\mathrm{z}<1)$

Where:

(l) is soil profile length ( $\mathrm{mm}$ ).

The boundary conditions for water and solute are given in terms of net mass fluxes by the following:

$\left(q_{l}+q_{v}\right)_{(0, t)}=E T_{0}, \quad n_{c(0, t)}=0$
$\left(q_{l}+q_{v}\right)_{(l, t)}=0, \quad n_{c(l, t)}=k_{S}$

Where :

$\mathrm{ET}_{0}$ is the daily potential evapotranspiration $\left(\mathrm{mm} \mathrm{d}^{-1}\right)$ and $\mathrm{Ks}$ is the saturated hydraulic conductivity $\left(\mathrm{mm} \mathrm{d}^{-1}\right)$.

The water and inorganic chemical transfer properties were described in detail (Nassar and Horton, 1997).

Visual comparison of simulated and observed data provides a quick and often comprehensive mean of assessing the accuracy of model prediction. However, quantitative evaluation of the model is recommended. In the present work, root mean square error (RMSE), modeling efficiency (ME), the coefficient of residual mass $(C R M)$ and Correlation coefficient $(\mathrm{r})$ as criteria for evaluating the model are used as criteria (Jabor et al., 1994; and Xevi et al., 1996).

These parameters were calculated as followes

$$
\begin{aligned}
& R M S E=\left(\sum_{i=1}^{n}\left(S_{i}-O_{i}\right)^{2} / n\right)^{1 / 2} *(100 / \bar{O}) \\
& M E=\sum_{i=1}^{n}\left(O_{i}-\bar{O}\right)^{2} / \sum_{i=1}^{n}\left(S_{i}-\bar{O}\right)^{2} \\
& C R M=\left(\sum_{i=1}^{n} O_{i}-\sum_{i=1}^{n} S_{i}\right) / \sum_{i=1}^{n} O_{i} \\
& r=\sum_{i=1}^{n}\left(O_{i}-\bar{O}\right)(S-\bar{S}) / \sqrt{\sum\left(O_{i}-\bar{O}\right)^{2} * \sum\left(S_{i}-\bar{O}\right)^{2}}
\end{aligned}
$$

Where:

$O$ and $S$ are the observed and simulated values, respectively. The over lined characters represent mean values

\section{RESULTS AND DISCUSSION}

\section{Soil Hydraulic properties}

The soil -moisture characteristics curves for compacted (1.67 $\mathrm{Mg} \mathrm{m}^{-3}$ ) and non-compacted (1.41 Mg $\mathrm{m}^{-3}$ ) soils are presented in Fig. (4). The curves showed that the amount of moisture retained at saturation is higher at low bulk density (without compaction) than at high bulk density (compacted soils). By increasing suction, difference in the retained water between compacted and non-compacted soil was diminished gradually. This was due to the reduction of soil 
macropores and increase of both slowly drainable and fine capillary pores with increasing soil bulk density (Klute, 1986a).

The total porosity and pore size distributions, as calculated from the soil-moisture characteristics curves, are shown in Table (2). Increasing soil bulk density (resulted from a localized soil compaction) decreased the total porosity by $21.8 \%$ in comparison to noncompacted soils. The pores $>30 \mu \mathrm{m}$ was reduced from 51 to $30.8 \%$ by increasing the bulk density. Similar resulted were reported by Mooney and Nipattasuk (2003) and Peng et al., 2004) who showed that the quickly drainable pores, slowly drainable pores and fine capillary pores decreased by $39.6,67.51$ and $68.47 \%$, respectively, by compaction.

The data also declare that increasing soil density, from 1.14 to $1.67 \mathrm{Mg} \mathrm{m}^{-3}$, decreased infiltration rate and saturated hydraulic conductivity by 60.6 and $70.0 \%$, respectively in comparison to un-compacted soil. These reductions may be due to localized compaction which may close large cracks and pores just beneath the fertilizer band behind the compacted soil. These results agree with those obtained by EL-Nady (2004).

\section{Plant growth parameters}

The plant growth parameters (plant height, total biomass production, stem diameter, number of leaves per plant, leaves fresh and dry weights and total dry matter) are listed in Table (3). The F.C. irrigation treatment (I-1) produced high leaf surface area/plant, plant height, leaves number/plant, stem diameter, leaves dry weight, plant biomass production and total dry matter in comparison to irrigation at SAT (I-2). The increasing percentages of these parameters were 62.29 ,
$18.46,20.15,12.87,62.92$, and $65.74 \%$, respectively in comparison to irrigation at saturation. These growth parameters differed significantly between the two irrigation treatments. The F.C. irrigation (I-1) regime did not exhibit response to localized compaction treatments. These results may be due to the limited leaching of nitrate. The growth parameters receiving compaction levels LC-1 and LC-2 differed significantly (5\% significance level) as compared to either the compaction levels of LC-3 or LC-4. Thus, it can be recommended to use compaction above the fertilization band or combination of compaction above and beneath the fertilization band. The latter compactions patterns produced high growth parameters. There were no significant different in plant growth parameters between treatments LC-3 and LC-4. Under LC-2 treatment, the fertilizer band was subjected completely to water movement and this promotes nitrate leaching (Kiuchi et al., 1996). The leached nitrate leads to a shortage of the amount of available nitrogen for plant uptake.

\section{Yield components:}

Irrigation at F.C. (I-1) increased grain yield, ear weight, ear tall, and ear diameter by $47.47 \%$, $46.69 \%$, $19.55 \%$ and $4.18 \%$, respectively, in comparison to the irrigation level of saturation (I-2) Table (4). The high percentages of yield components are attributed to high concentration of nitrate under F.C. irrigation (I-1) in comparison to its concentration using saturation irrigation (I-2). These results support the growth parameters results (Table 3). Additionally, these results are in agreement with those obtained by Aggag (2001) and Diez (1997).

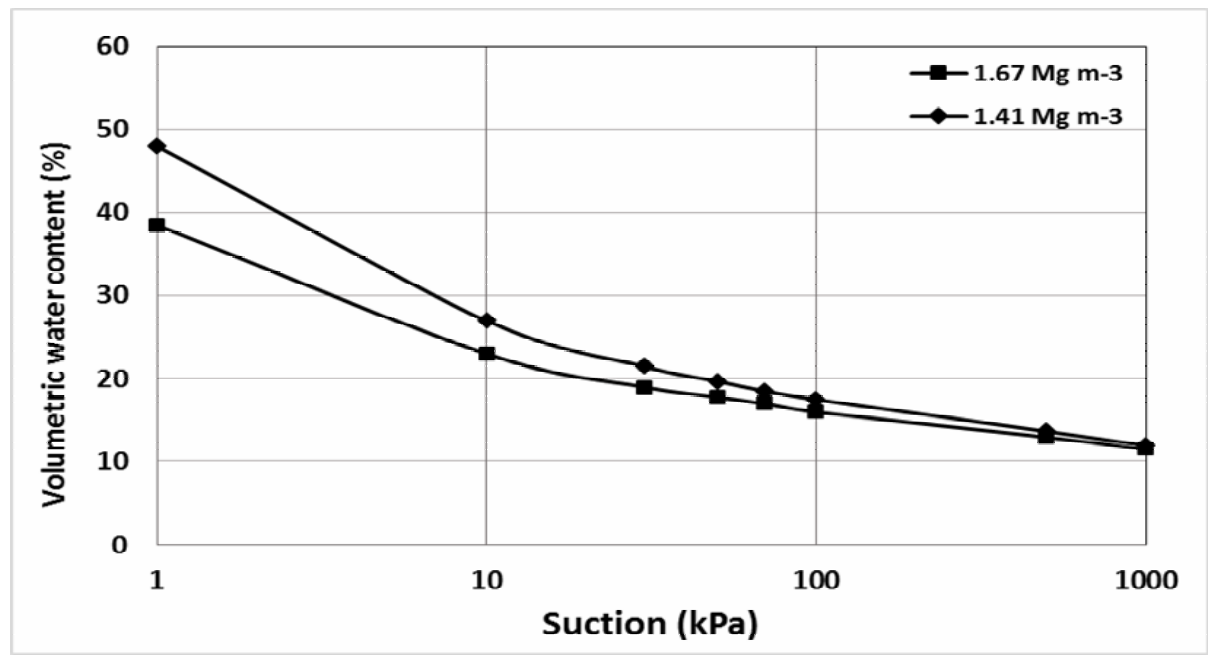

Fig. 4. Soil moisture characteristics curves for the soil samples under two bulk densities 
Table 2. Values of total porosity and pore size distribution as a percentage of total porosity of the soil samples at the two bulk densities

\begin{tabular}{|c|c|c|c|c|c|}
\hline \multirow[b]{2}{*}{$\begin{array}{l}\text { Soil bulk density } \\
\left(\mathrm{Mg} \mathrm{m}^{-3}\right)\end{array}$} & \multicolumn{5}{|c|}{ Pore size distribution as a percentage of total porosity } \\
\hline & $\begin{array}{c}\text { Total } \\
\text { porosity }(\%)\end{array}$ & $\begin{array}{c}\text { Quickly } \\
\text { drainable } \\
\text { pores } \\
>\mathbf{3 0} \boldsymbol{\mu m} \\
\end{array}$ & $\begin{array}{c}\text { Slowly drainable } \\
\text { pores } \\
(30-9) \mu \mathrm{m}\end{array}$ & $\begin{array}{c}\text { Water holding } \\
\text { pores } \\
(9-0.2) \mu \mathrm{m}\end{array}$ & $\begin{array}{c}\text { Fine capillary } \\
\text { pores } \\
<0.2 \mu \mathrm{m}\end{array}$ \\
\hline 1.41 & 47.17 & 51.00 & 12.81 & 19.32 & 16.87 \\
\hline 1.67 & 36.89 & 30.80 & 21.46 & 19.37 & 28.36 \\
\hline
\end{tabular}

Table 3. The values of leaf surface area (L.S.A), plant height, number of leaves, stem diameter, leaves fresh weight (L.F.W), leaves dry weight(L.D.W), plant biomass production (P.B.P) and total dry matter (T.D.W) of maize plant as a result of irrigation and compaction treatments

\begin{tabular}{|c|c|c|c|c|c|c|c|c|c|}
\hline & $\begin{array}{l}\text { reatmen } \\
\qquad t\end{array}$ & $\begin{array}{c}\text { L.S.A. } \\
\left(\mathrm{m}^{2} / \text { plant }\right)\end{array}$ & $\begin{array}{c}\text { Plant } \\
\text { height }(\mathbf{c m})\end{array}$ & $\begin{array}{l}\text { Number of } \\
\text { leaves/ plant }\end{array}$ & $\begin{array}{c}\text { Stem } \\
\text { diameter(cm) }\end{array}$ & $\begin{array}{l}\text { L.F.W. } \\
\text { (g/plant) }\end{array}$ & $\begin{array}{l}\text { L.D.W. } \\
\text { (g/plant) }\end{array}$ & $\begin{array}{l}\text { P.B.P. } \\
\text { (g/plant) }\end{array}$ & $\begin{array}{l}\text { T.D.W. } \\
\text { (g/plant) }\end{array}$ \\
\hline \multicolumn{10}{|c|}{ Irrigation } \\
\hline \multicolumn{2}{|c|}{ F.C. (I-1) } & $0.99 \mathrm{a}$ & $258.26 \mathrm{a}$ & $15.86 \mathrm{a}$ & $2.79 \mathrm{a}$ & $341.25 \mathrm{a}$ & $114.77 \mathrm{a}$ & $1181.3 \mathrm{a}$ & $342.28 \mathrm{a}$ \\
\hline \multicolumn{2}{|c|}{ SAT (I-2) } & $0.61 \mathrm{~b}$ & $217.96 \mathrm{~b}$ & $13.21 \mathrm{~b}$ & $2.47 \mathrm{~b}$ & $209.45 \mathrm{~b}$ & $67.70 \mathrm{~b}$ & $750.13 \mathrm{~b}$ & $206.06 \mathrm{~b}$ \\
\hline \multicolumn{2}{|c|}{$\mathrm{LSD}_{0.05}$} & 0.10 & 3.16 & 0.33 & 0.20 & 38.82 & 15.71 & 98.02 & 75.30 \\
\hline \multicolumn{10}{|c|}{ Compaction } \\
\hline \multicolumn{2}{|c|}{ LC-1 } & $0.76 \mathrm{~b}$ & $229.36 \mathrm{~b}$ & $14.36 \mathrm{~b}$ & $2.61 \mathrm{bc}$ & $256.0 \mathrm{~b}$ & $85.39 \mathrm{~b}$ & $906.50 \mathrm{~b}$ & $261.36 \mathrm{~b}$ \\
\hline \multicolumn{2}{|c|}{ LC-2 } & $0.73 \mathrm{~b}$ & $229.49 \mathrm{~b}$ & $13.94 \mathrm{c}$ & $2.55 \mathrm{~b}$ & $257.08 \mathrm{~b}$ & $86.11 \mathrm{~b}$ & $887.50 \mathrm{~b}$ & $241.67 \mathrm{~b}$ \\
\hline \multicolumn{2}{|c|}{ LC-3 } & $0.86 \mathrm{a}$ & $245.31 \mathrm{a}$ & $14.81 \mathrm{a}$ & $2.64 \mathrm{a}$ & $288.75 \mathrm{a}$ & $96.88 \mathrm{a}$ & $1045.42 \mathrm{a}$ & $292.61 \mathrm{a}$ \\
\hline \multicolumn{2}{|c|}{ LC-4 } & $0.85 \mathrm{a}$ & $248.28 \mathrm{a}$ & $15.03 \mathrm{a}$ & $2.87 \mathrm{a}$ & $299.58 \mathrm{a}$ & $96.58 \mathrm{a}$ & $1023.33 \mathrm{a}$ & $299.56 \mathrm{a}$ \\
\hline \multicolumn{2}{|c|}{$\operatorname{LSD}_{0.05}$} & 0.06 & 5.73 & 0.35 & 0.20 & 16.87 & 8.85 & 79.42 & 37.51 \\
\hline \multicolumn{10}{|c|}{ Compaction X irrigation } \\
\hline \multirow{4}{*}{$\mathrm{I}-1$} & $\underline{\mathrm{LC}}-1$ & $1.02 \mathrm{a}$ & $258.06 \mathrm{a}$ & $16.00 \mathrm{a}$ & $2.87 \mathrm{a}$ & $338.33 \mathrm{a}$ & $112.78 \mathrm{a}$ & $1185.83 \mathrm{a}$ & $350.00 \mathrm{a}$ \\
\hline & $\mathrm{LC}-2$ & $0.98 \mathrm{a}$ & $261.67 \mathrm{a}$ & $15.72 \mathrm{a}$ & $2.76 \mathrm{~b}$ & $345.00 \mathrm{a}$ & $117.04 \mathrm{a}$ & $1188.33 \mathrm{a}$ & $319.75 \mathrm{a}$ \\
\hline & LC-3 & $0.98 \mathrm{a}$ & $256.56 \mathrm{a}$ & $15.89 \mathrm{a}$ & $2.76 \mathrm{~b}$ & $329.17 \mathrm{a}$ & $114.94 \mathrm{a}$ & $1172.50 \mathrm{a}$ & $332.71 \mathrm{a}$ \\
\hline & LC-4 & $0.99 \mathrm{a}$ & $256.83 \mathrm{a}$ & $15.83 \mathrm{a}$ & $2.76 \mathrm{~b}$ & $342.94 \mathrm{a}$ & $114.36 \mathrm{a}$ & $1178.33 \mathrm{a}$ & $333.33 \mathrm{a}$ \\
\hline \multirow{4}{*}{$\mathrm{I}-2$} & LC-1 & $0.50 \mathrm{c}$ & $200.67 \mathrm{~b}$ & $12.72 \mathrm{c}$ & $2.35 \mathrm{~d}$ & $173.67 \mathrm{c}$ & $58.01 \mathrm{c}$ & $627.17 \mathrm{c}$ & $161.11 \mathrm{c}$ \\
\hline & $\underline{\mathrm{LC}-2}$ & $0.48 \mathrm{c}$ & $197.39 \mathrm{~b}$ & $12.27 \mathrm{c}$ & $2.33 \mathrm{~d}$ & $169.17 \mathrm{c}$ & $55.19 \mathrm{c}$ & $586.67 \mathrm{c}$ & $152.83 \mathrm{c}$ \\
\hline & LC-3 & $0.74 \mathrm{~b}$ & $234.06 \mathrm{c}$ & $13.72 \mathrm{~b}$ & $2.53 \mathrm{c}$ & $248.33 \mathrm{~b}$ & $78.82 \mathrm{~b}$ & $918.33 \mathrm{~b}$ & $239.50 \mathrm{~b}$ \\
\hline & LC-4 & $0.71 \mathrm{~b}$ & $239.72 \mathrm{c}$ & $14.22 \mathrm{~b}$ & $2.69 \mathrm{~b}$ & $246.67 \mathrm{~b}$ & $78.80 \mathrm{~b}$ & $868.33 \mathrm{~b}$ & $252.46 \mathrm{~b}$ \\
\hline \multicolumn{2}{|c|}{$\mathrm{LSD}_{0.05}$} & 0.12 & 7.54 & 0.52 & 0.10 & 41.72 & 18.03 & 131.20 & 82.88 \\
\hline \multicolumn{5}{|c|}{$\begin{array}{l}\text { The results showed that compaction treatments } \\
\text { significantly affected the yield components (Table 4). } \\
\text { The maximum values of total grain yield, ear weight, } \\
\text { ear tall, ear diameter and number of rows were obtained } \\
\text { in the treatments LC-3 and LC-4. This may be due to } \\
\text { the effect of soil localized compaction on protecting the } \\
\text { plant nutrients from leaching. This points out that, the } \\
\text { best compaction treatments were the compaction above } \\
\text { the fertilizer band or a combination of compaction } \\
\text { above and beneath the fertilization band. These results } \\
\text { are in agreement with those reported for growth } \\
\text { parameters (Table 3). }\end{array}$} & \multicolumn{5}{|c|}{$\begin{array}{l}\text { For the interaction between irrigation and } \\
\text { compaction treatments, the results showed that there } \\
\text { were no significant differences between treatments } \\
\text { under F.C. irrigation (I-1). This may be due to that there } \\
\text { is no excess water to leach nitrate out of root zone. } \\
\text { However, there were high significant differences } \\
\text { between irrigation treatments: I-2 and I-1. This may be } \\
\text { due to leaching of nitrate by excess water applied in } \\
\text { saturation treatment (I-2) as compared with those due to } \\
\text { F.C. irrigation (I-1). Under F.C. (I-1) treatments, there } \\
\text { were significant differences between treatments due to } \\
\text { soil compaction. When the compacted layer was under } \\
\text { the fertilizer band, compaction has no effect in }\end{array}$} \\
\hline
\end{tabular}


preventing nitrate loss by leaching (Ressler et al., 1998b and Seo et al., 2005).

\section{Nitrogen uptake and nitrate leaching:}

Total nitrogen uptake (grain-N + straw-N) by maize and total-N as percent of applied-N are listed in Table (5). Total nitrogen uptake increased by $59.49 \%$ by low water irrigation pattern (F.C., I-1) in comparison with high irrigation (I-2) (Table 7). For compaction treatments, the total nitrogen uptakes were 253.80, $243.33,249.56$ and $247.42 \mathrm{~kg} \mathrm{ha}^{-1}$, for LC-1, CL-2, LC3 and LC-4, respectively for irrigation I- 1 . This can be attributed to low leaching out of nitrate from root zone. There were no significant differences between treatments under this level (I-1) of irrigation. The corresponding values for irrigation treatment (I-2) were 117.74, 109.86, 195.27 and $200.65 \mathrm{~kg} \mathrm{ha}^{-1}$. Similar results were reported by Gardenas et al. (2005) and Alva et al. (2006). Generally, the average nitrogen uptake components was higher under I-1 irrigation than under I-2 irrigation. For example, on the average, the total nitrogen uptakes were 248.53 and $155.88 \mathrm{~kg} \mathrm{ha}^{-1}$ under I-1 and I-2 irrigation treatments, respectively. These results are in parallel accordance with both the growth and yield components (Tables 3 and 4).

Table 4. The values of grain yield (ton/ha), ear weight (g), ear tall (cm), number of rows per ear and ear diameter $(\mathrm{cm})$ as influenced by irrigation and compaction treatments

\begin{tabular}{|c|c|c|c|c|c|c|}
\hline \multicolumn{2}{|c|}{ Treatment } & $\begin{array}{l}\text { Grain yield } \\
\text { (ton/ha) }\end{array}$ & Ear weight (g) & Ear tall $(\mathrm{cm})$ & $\begin{array}{c}\text { Ear diameter } \\
(\mathrm{cm})\end{array}$ & $\begin{array}{c}\text { Number of } \\
\text { rows/ear }\end{array}$ \\
\hline \multicolumn{7}{|c|}{$\begin{array}{l}\text { Irrigation } \\
\end{array}$} \\
\hline \multicolumn{2}{|l|}{ I-1 } & $9.05 \mathrm{a}$ & $294.94 \mathrm{a}$ & $20.73 \mathrm{a}$ & $5.47 \mathrm{a}$ & $13.94 \mathrm{a}$ \\
\hline \multicolumn{2}{|l|}{$\mathrm{I}-2$} & $6.14 \mathrm{~b}$ & $201.07 \mathrm{~b}$ & $17.34 \mathrm{~b}$ & $5.25 \mathrm{~b}$ & $13.75 \mathrm{a}$ \\
\hline \multicolumn{2}{|c|}{ LSD 0.05} & 0.37 & 18.30 & 0.43 & 0.19 & 0.54 \\
\hline \multicolumn{7}{|c|}{ Compaction } \\
\hline \multicolumn{2}{|c|}{ LC-1 } & $7.24 \mathrm{~b}$ & $232.12 \mathrm{~b}$ & $18.63 \mathrm{~b}$ & $5.37 \mathrm{~b}$ & $13.69 \mathrm{~b}$ \\
\hline \multicolumn{2}{|c|}{$\mathrm{LC}-2$} & $6.82 \mathrm{~b}$ & $227.05 \mathrm{~b}$ & $18.31 \mathrm{~b}$ & $5.27 \mathrm{~b}$ & $13.78 \mathrm{ab}$ \\
\hline \multicolumn{2}{|c|}{ LC-3 } & $8.37 \mathrm{a}$ & $267.63 \mathrm{a}$ & $19.63 \mathrm{a}$ & $5.38 \mathrm{a}$ & $13.86 \mathrm{ab}$ \\
\hline \multicolumn{2}{|c|}{ LC-4 } & $7.93 \mathrm{a}$ & $265.22 \mathrm{a}$ & $19.66 \mathrm{a}$ & $5.4 \mathrm{a}$ & $14.07 \mathrm{a}$ \\
\hline \multicolumn{2}{|c|}{ LSD 0.05} & 0.47 & 7.61 & 0.36 & 0.14 & 0.32 \\
\hline \multicolumn{7}{|c|}{ Compaction $\mathrm{X}$ irrigation } \\
\hline \multirow{4}{*}{ I-1 } & LC-1 & $9.22 \mathrm{a}$ & $297.95 \mathrm{a}$ & $20.92 \mathrm{a}$ & $5.44 \mathrm{ab}$ & $13.91 \mathrm{ab}$ \\
\hline & LC-2 & $8.94 \mathrm{a}$ & $293.62 \mathrm{a}$ & $20.66 \mathrm{a}$ & $5.48 \mathrm{a}$ & $13.78 \mathrm{ab}$ \\
\hline & $\mathrm{LC}-3$ & $9.21 \mathrm{a}$ & $296.14 \mathrm{a}$ & $20.70 \mathrm{a}$ & $5.44 \mathrm{ab}$ & $13.78 \mathrm{ab}$ \\
\hline & LC-4 & $8.82 \mathrm{a}$ & $292.06 \mathrm{a}$ & $20.65 \mathrm{a}$ & $5.47 \mathrm{a}$ & $14.18 \mathrm{a}$ \\
\hline \multirow{5}{*}{$\mathrm{I}-2$} & $\mathrm{LC}-1$ & $5.27 \mathrm{c}$ & $166.30 \mathrm{c}$ & $16.35 \mathrm{c}$ & $5.25 \mathrm{~b}$ & $13.47 \mathrm{~b}$ \\
\hline & $\mathrm{LC}-2$ & $4.90 \mathrm{c}$ & $160.48 \mathrm{c}$ & $15.77 \mathrm{c}$ & $5.09 \mathrm{c}$ & $13.64 \mathrm{ab}$ \\
\hline & LC-3 & $7.53 \mathrm{~b}$ & $239.13 \mathrm{~b}$ & $18.56 \mathrm{~b}$ & $5.33 b$ & $13.96 \mathrm{ab}$ \\
\hline & $\mathrm{LC}-4$ & $7.05 \mathrm{~b}$ & $238.38 \mathrm{~b}$ & $18.66 \mathrm{~b}$ & $5.39 \mathrm{~b}$ & $14.09 \mathrm{ab}$ \\
\hline & LSD 0.05 & 0.66 & 19.51 & 0.59 & 0.13 & 0.63 \\
\hline
\end{tabular}

\section{Water Efficiency:}

Table (6) showed that average values of WUE, WUTE and BPE were $1.25,0.871$, and $8.876 \mathrm{~kg} / \mathrm{m}^{3}$, respectively, under F.C. irrigation (I-1). Their corresponding values for saturation irrigation (I-2) were $0.853,0.147$, and $5.647 \mathrm{~kg} \mathrm{~m}^{-3}$, respectively. The water efficiencies under I-1 irrigation were greater than under saturation irrigation (I-2). The values of WUE were $0.723,0.677,1.040$ and 0.974 for LC-1, LC-2, LC-3, and LC-4, respectively under I-2 which are lower than those at F.C. (I-1) treatment. Thus, the presence of compacted soil layer had reduced water deep percolation which lead to high water efficiencies.

In addition, the compacted layer act to increase the amount of mineral nitrogen subjected to plant uptake. Hence, grain yield and biomass production increased as a result of the increase in available mineral nitrogen in the root zone. However, when the compacted layer was beneath the fertilizer band, this fertilizer was completely exposed to the water, and that the compacted layer did not divert water movement around the fertilizer (Brindha and Elango, 2014). 
Table 5. The values of total $\mathrm{N}$-uptake and total $\mathrm{N}$-uptake as a percentage of nitrogen applied as affected by irrigation and localized compaction treatments

\begin{tabular}{|c|c|c|c|c|c|}
\hline & \multirow{2}{*}{ Treatments } & Grain-N & straw-N & Total-N uptake & \multirow{2}{*}{$\begin{array}{c}\text { Total-N as \% of } \\
\text { applied-N }\end{array}$} \\
\hline & & \multicolumn{3}{|c|}{$\mathrm{kg} \mathrm{ha}^{-1}$} & \\
\hline \multirow{5}{*}{$\mathrm{I}-1$} & LC-1 & 78.94 & 174.85 & 253.80 & 88.87 \\
\hline & LC-2 & 76.56 & 166.76 & 243.33 & 85.21 \\
\hline & LC-3 & 78.89 & 170.66 & 249.56 & 87.38 \\
\hline & LC-4 & 75.54 & 171.88 & 247.42 & 86.64 \\
\hline & Average & 77.48 & 171.04 & 248.53 & 87.03 \\
\hline \multirow{5}{*}{$\mathrm{I}-2$} & LC-1 & 45.12 & 72.61 & 117.74 & 46.21 \\
\hline & LC-2 & 42.00 & 67.85 & 109.86 & 43.71 \\
\hline & LC-3 & 64.52 & 130.75 & 195.27 & 68.38 \\
\hline & LC-4 & 60.40 & 140.25 & 200.65 & 70.26 \\
\hline & Average & 48.51 & 102.87 & 155.88 & 57.14 \\
\hline
\end{tabular}

Table 6. The values of water efficiencies for maize as affected by irrigation and localized compaction treatments

\begin{tabular}{|c|c|c|c|c|}
\hline \multirow{2}{*}{\multicolumn{2}{|c|}{ Treatments }} & WUE & WUTE & BPE \\
\hline & & \multicolumn{3}{|c|}{$\left(\mathrm{kg} / \mathrm{m}^{3}\right)$} \\
\hline \multirow{4}{*}{ I-1 } & LC-1 & 1.273 & 0.888 & 8.911 \\
\hline & LC-2 & 1.234 & 0.861 & 8.930 \\
\hline & LC-3 & 1.273 & 0.887 & 8.811 \\
\hline & LC-4 & 1.218 & 0.85 & 8.854 \\
\hline & & 1.250 & 0.871 & 8.876 \\
\hline \multirow{4}{*}{ I-2 } & LC-1 & 0.723 & 0.126 & 4.713 \\
\hline & LC-2 & 0.677 & 0.117 & 4.408 \\
\hline & LC-3 & 1.040 & 0.179 & 6.901 \\
\hline & LC-4 & 0.974 & 0.166 & 6.525 \\
\hline & & 0.853 & 0.147 & 5.637 \\
\hline
\end{tabular}

Table 7. Nitrogen use efficiencies for maize during the growing season as affected by irrigation and localized compaction treatments

\begin{tabular}{|c|c|c|c|c|c|}
\hline \multirow{2}{*}{\multicolumn{2}{|c|}{ Treatments }} & NUE & GNAE & NBPE & NUTE \\
\hline & & \multicolumn{4}{|c|}{$(\mathrm{kg} / \mathrm{kg})$} \\
\hline \multirow{4}{*}{$\mathrm{I}-1$} & LC-1 & 32.25 & 0.23 & 225.78 & 205.75 \\
\hline & LC-2 & 31.28 & 0.21 . & 226.25 & 208.13 \\
\hline & LC-3 & 32.24 & 0.22 & 223.244 & 209.12 \\
\hline & LC-4 & 30.86 & 0.22 & 224.35 & 201.95 \\
\hline & & 31.67 & 0.22 & 224.90 & 206.24 \\
\hline \multirow{4}{*}{$\mathrm{I}-2$} & LC-1 & 18.43 & 0.13 & 119.41 & 253.54 \\
\hline & LC-2 & 17.15 & 0.12 & 111.70 & 252.89 \\
\hline & LC-3 & 26.36 & 0.18 & 174.85 & 218.53 \\
\hline & LC-4 & 24.68 & 0.17 & 165.33 & 199.13 \\
\hline \multicolumn{2}{|c|}{ Average } & 21.48 & 0.15 & 142.82 & 231.02 \\
\hline
\end{tabular}


Table 8. the values of compaction dependency (\%) for yield components of maize plant

\begin{tabular}{clccccc}
\hline & Treatments & Ear diameter & Ear tall & Ear weight & Weight of 100 kernel Grain yield \\
\hline \multirow{2}{*}{ LC-2 } & 0.85 & -1.23 & -1.45 & 1.60 & -3.01 \\
\cline { 2 - 7 } LC-3 & 0.14 & -1.03 & -0.61 & -0.96 & -0.06 \\
\cline { 2 - 7 } & LC-4 & 0.70 & -1.26 & -1.97 & -0.62 & -4.31 \\
\hline \multirow{2}{*}{ average } & 0.56 & -1.17 & -1.34 & 0.01 & -2.46 \\
\hline \multirow{2}{*}{ I-2 } & LC-2 & -2.95 & -3.53 & -3.78 & -2.62 & -6.99 \\
\cline { 2 - 7 } & LC-4 & 1.57 & 13.57 & 43.80 & 2.17 & 42.97 \\
\cline { 2 - 7 } & average & 2.83 & 14.17 & 43.35 & 1.84 & 33.86 \\
\hline
\end{tabular}

Nitrogen Efficiency:

For F.C. Irrigation treatment (I-1), the values of nitrogen efficiencies (NUE, NBPE and GNAE) were increased by $47.43,57.45 \%$ and $46.67 \%$, respectively, while NUTE decreased by $10.73 \%$ as compared to their levels for saturation irrigation (I-2). These results are in agreement with nitrogen uptake and growth parameters. Under Irrigation level (I-1), there are no significant differences between localized compaction treatments, which are attributed to minimizing the water and nitrogen losses from the plant root zone while under saturation (I-2) treatment, localized compaction changed NUE by $-6.94,43.03$ and $33.91 \%$; BNPE by -6.45 , 46.42 and $38.45 \%$; GNAE by $-7.69,38.46$, and $30.77 \%$ for LC2, LC-3, and LC-4, respectively as compared to the control treatment. The increasing in nitrogen use efficiencies due to localized compaction may be due to the decrease of leaching losses by deep percolation of added mineral nitrogen. On the other hand, NUTE changed by $-0.26,-13.81$ and $-21.46 \%$ for LC2, LC-3, and LC-4, respectively, as compared to the control treatment.

These data suggest that the compacted soil layer above or both above and under the fertilizer band was the main factor for high nitrogen availability and high yield (Ressler et al., 1997). However, when the compacted layer was only under the fertilizer band, the fertilizer was completely appeared in the leached water. This compacted layer did not divert water movement around the band of fertilizers so water will carry the fertilizer and leached it out of root zone.

\section{Compaction dependency:}

Table 8 showed that under I-1 irrigation treatment, the average values of compaction dependencies were $0.56,-1.17,-1.34,0.01$ and $-2.46 \%$ for ear diameter, ear tall, ear weight, weight of 100 kennel and grain yield, respectively. The corresponding compaction dependencies for saturation irrigation (I-2) were 0.48 ,
$8.07,27.79,0.46$, and 23.32, respectively. The negative values of compaction dependency mean that compaction did not affect the yield parameters. For example, the ear tall produced by LC- 2 under I-1 irrigation is lower than its value under the control treatment. It is obvious that compaction affects positively the yield components under saturation irrigation (I-2). This may be due to the localized compaction, which may reduce $\mathrm{NO}_{3}^{-}$leaching and improve $\mathrm{N}$-use efficiency at heavy application of water on maize field during growing season.

In general, plots received localized compaction under F.C. irrigation (I-1) yielded an average of 23.32\% more than plots under I-2 irrigation. Under I-2, plots received localized compaction (LC-3) and (LC-4) yielded 42.97 and $33.86 \%$ more than plots of the control (LC-1), respectively. Thus, compaction associated with irrigation at field capacity produced the best growth parameters for maize. These results are in agreement with those reported by Baker et al., (1997), Ressler et al. (1998-a), Kiuchi et al. (1996) and Baker (2002).

\section{Fate of soil nitrate}

The nitrate concentrations in soil profiles and leachates are studied experimentally and theoretically. The experimental concentrations were measured in the leached soil solution and soil profile while the theoretical values are obtained using the LEACHM model. The data in Figure (5) indicate that leaching losses decreased with decreasing the amount of irrigation water from saturation to field capacity by $75.68 \%$ in comparison to the saturation treatment. The average leaching losses for localized compaction treatments under I-1 irrigation treatment were 36.43, $38.10,31.22$ and $31.86 \mathrm{~kg} \mathrm{ha}^{-1}$ for LC-1, LC-2, LC-3, and LC-4, respectively. There were no significant differences between localized compaction treatments under field capacity irrigation treatment (I-1). These data agree with those obtained by Zhao et al. (2011). 


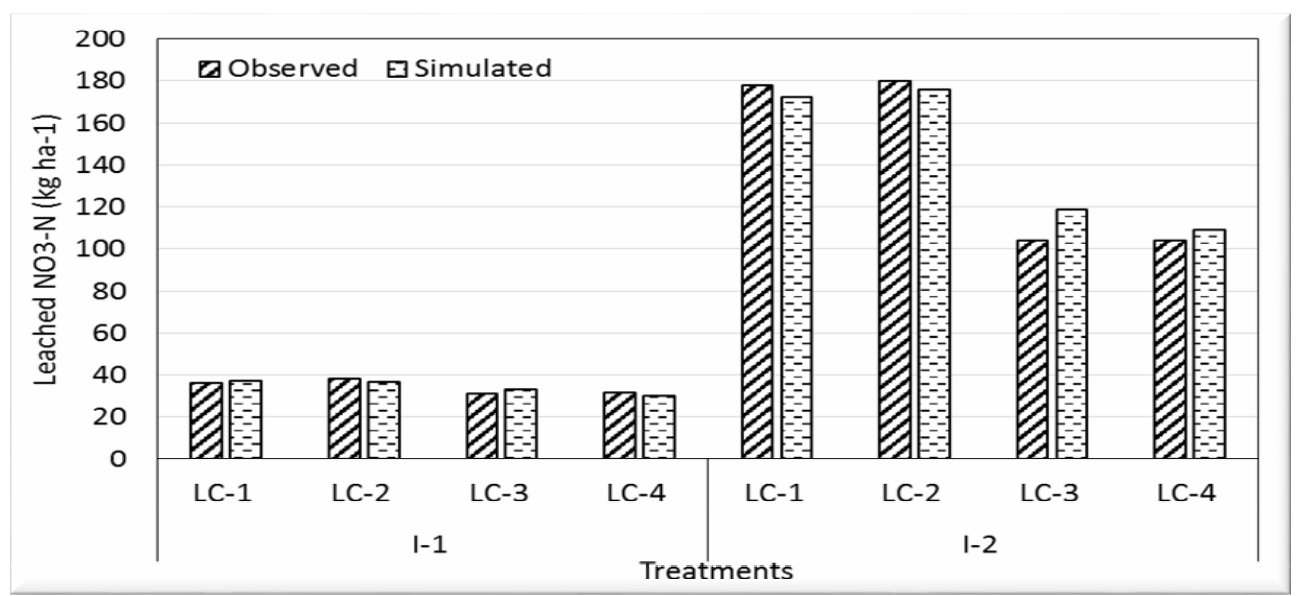

Fig. 5. Observed and simulated leached $\mathrm{NO}_{3}-\mathrm{N}$ under water and localized compaction treatments

Under saturation irrigation treatment (I-2), the average leaching losses for localized compaction treatments were $177.76,179.85,104.31$ and $103.93 \mathrm{~kg}$ $\mathrm{ha}^{-1}$ for LC-1, LC-2, LC-3, and LC-4, respectively. Additionally, nitrate losses in LC-3 treatments and LC-4 were lower than either LC-1 or LC-2. The compacted layer increased the amount of nitrate available for plant uptake that lowered its leached. There were no significant differences between (LC-2) and the control (LC-1), in leaching losses because the fertilizer band was completely exposed to water and the surrounding soil is more favorable for water movement. Excessive water application above a soil field capacity led to deep percolation and possible $\mathrm{NO}_{3}^{-}$leaching. The LEACH model well described the $\mathrm{NO}_{3}^{-}$concentration in comparison to the observed values. So, the model is able to describe $\mathrm{NO}_{3}^{-}$fate under the conditions of the present study. Thus, our results are in agreement with those reported by Pathak et al. (2004); Sumanasena et al. (2004); Feng et al. (2005) and Naoko et al. (2005). Kucharik and Barye (2003) reported that 30 percent increase of nitrate fertilizer consumed in maize leads to 56 percent annual leaching of nitrate, while the yield is improved only by 1 percent. If the amount of applied $\mathrm{N}$ decreased by about $30 \%$, the amount of nitrate leached would be also decreased by about $42 \%$.

Soil nitrate distributions (theoretically and experimentally), at the end of the growth season, are illustrated in Figure (6). The theoretical values were obtained by using the LEACH model. Both the observed and theoretical trends were similar. The model successfully predicted the nitrate concentration in comparison to the observed values. So, the model efficiency for describing the nitrate is high which enhance using the model in nitrate application managements. Under I-2 irrigation treatments, the obtained pattern of nitrate distributions in the soil profile suggests that the transport was dominated by convective transport for nitrate. Nitrate moved below $70-\mathrm{cm}$ depth has the maximum concentration (12.78 ppm). However, under irrigation I-1 treatment, the data showed that low amount of nitrate had moved downward below the $70-\mathrm{cm}$ depth. The peak nitrate concentration occurred in the layer of $30-50 \mathrm{~cm}$ in soil profiles under all compaction patterns. This peak ranged from 10.00 to $13.00 \mathrm{ppm}$ for the compaction patterns. The top layer of soil profile $(0-20 \mathrm{~cm})$ possessed the lowest concentration of nitrate for both of the irrigation treatments. Data also indicated that the average concentration of $\mathrm{NO}_{3}-\mathrm{N}$ in all the soil profile is 9.67 and $8.53 \mathrm{mg} \mathrm{l}^{-1}$ under irrigation treatments $\mathrm{I}-1$ and $\mathrm{I}-2$, respectively. For the profiles that received compaction (LC-3 or LC-4), high average nitrate concentration was present in the root zone (10.26 and $9.02 \mathrm{mg} / \mathrm{l}$, respectively), for F.C. irrigation I-1. The corresponding concentrations for I-2 irrigation treatment were 8.78 and 9.73 , respectively. The increase of permeability allows large quantity of water to leach and consequently increases the amount of nitrate reaching out of the root zone. These data agree with those obtained by Ressler et al. (1998-b) and Sumanasena et al. (2004).

\section{Model Evaluation:}

Model performance and simulation accuracy were evaluated based on its ability to predict $\mathrm{NO}_{3}-\mathrm{N}$ data at the end of the growing season. Evaluation of the model was conducted by comparing the observed and predicted $\mathrm{NO}_{3}-\mathrm{N}$ concentration in the soil profile and $\mathrm{NO}_{3}-\mathrm{N}$ leached under the profile for each irrigation regime and localized compaction treatments (Table 9). 

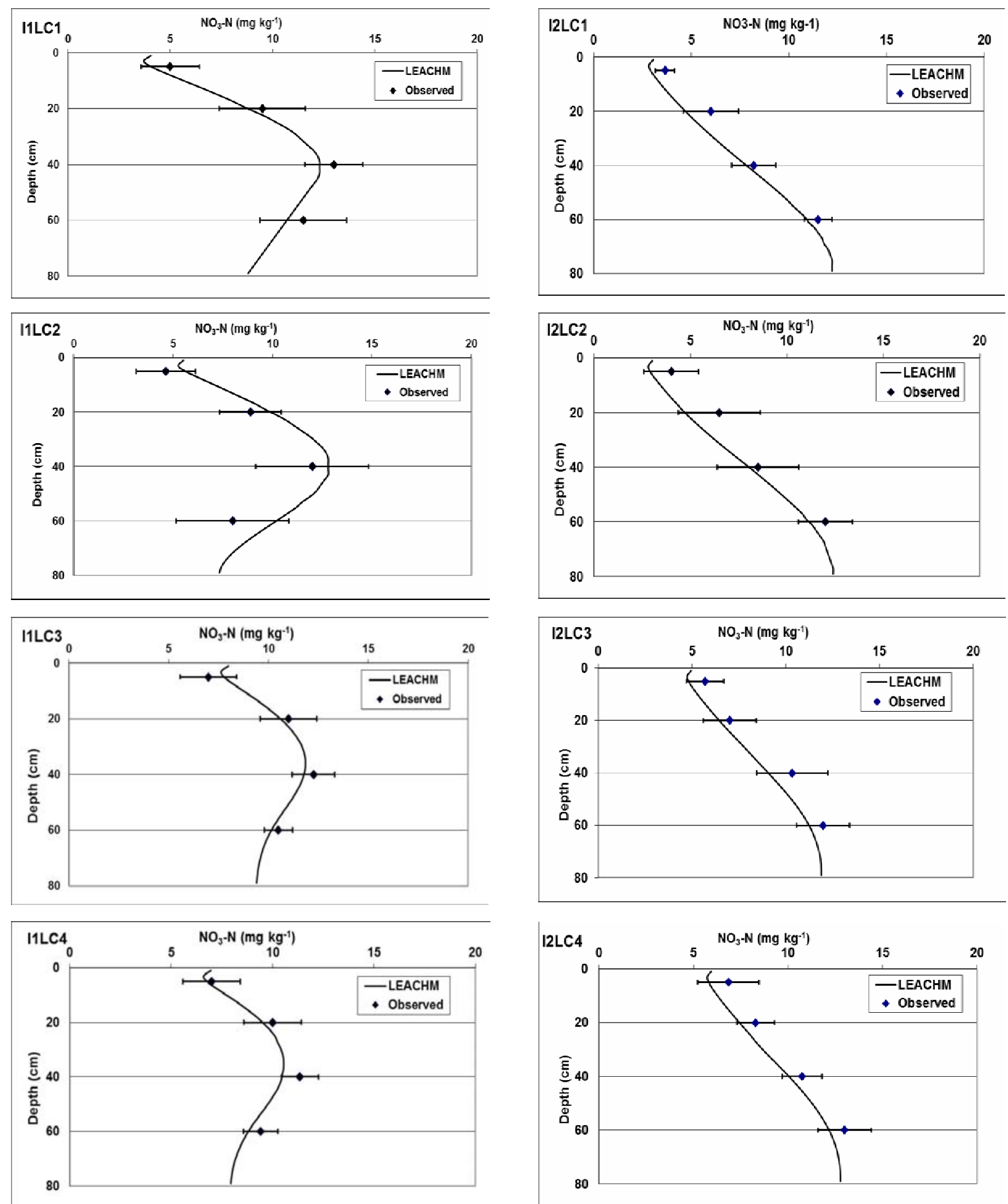

Fig. 6. Observed and simulated $\mathrm{NO}_{3}-\mathrm{N}$ concentrations in soil profile under water and localized compaction treatments 
Table 9. Statistical comparison between observed and simulated data

\begin{tabular}{|c|c|c|c|c|c|c|}
\hline \multirow{2}{*}{ Parameter } & \multicolumn{3}{|c|}{ Leached $\mathrm{NO}_{3}^{-}-\mathrm{N}$} & \multicolumn{3}{|c|}{$\mathrm{NO}_{3}^{-}-\mathrm{N}$ Conc. in profile } \\
\hline & I-1 & I-2 & Total & I-1 & I-2 & Total \\
\hline $\mathrm{ME}$ & 1.009 & 0.990 & 0.990 & 1.091 & 0.708 & 0.811 \\
\hline CRM & 0.003 & -0.018 & -0.014 & 0.006 & 0.105 & 0.052 \\
\hline RMSE & 4.282 & 5.835 & 6.743 & 9.530 & 11.236 & 10.239 \\
\hline $\mathrm{r}$ & 1.013 & 1.001 & 1.001 & 0.889 & 0.935 & 0.916 \\
\hline
\end{tabular}

Values of (r) under irrigation and localized compaction treatments indicate high correlation between simulated and observed data. The ME value is close to the unity which indicate the high performance of the model to predict nitrogen in soil and leachate. Similar finding was obtained using CRM. The RMSE values were ranged from 4.282 and 9.530 for leached nitrate and nitrate concentration in soil, respectively under F.C. (I-1) treatment. The corresponding RMSE values for saturation (I-2) treatment were 5.835 and 11.236. In general, LEACHM proved to be a good tool for the purpose of simulation of soil profile $\mathrm{NO}_{3}-\mathrm{N}$ concentration and leaching under different water regimes and soil localized compaction treatments. These data agree with those obtained by Ehteshami et al., (2013) and Nasri et al. (2015). Therefore, the LEACHM model is a promising tool for nitrate management under field conditions.

\section{CONCLUSION}

The results of this study showed that using $30 \mathrm{~kg}$ loads above the compacting wheel, increased soil bulk density from 1.41 up to $1.67 \mathrm{~g} \mathrm{~cm}^{-3}$. This caused parallel decreases in total porosity, quickly drainable pores and increased the slowly drainable pores and fine capillary pores that produced reduction in both of infiltration rate and hydraulic conductivity. Irrigation at field capacity significantly increased grain yield, N-uptake, all growth parameters, N-efficiency and water efficiency parameters, at the same time reduced nitrate leaching from soil profile as compared with irrigation at saturation. This behavior also noticed in irrigation at saturation combined with compacted layer above fertilizer band/both above and under fertilizer band. Irrigation at field capacity showed no significant response to localized compaction treatments. Therefore, localized compaction dependency was small as compared with irrigation as soil saturation. The results indicate that localized compaction (LC3 and LC-4) had reduced nitrate leaching and improved $\mathrm{N}$-use efficiency when irrigation water exceeded field capacity. The LEACHM model well predicted soil nitrate concentration and leaching under different water regimes and soil localized compaction treatments compared with the observed concentrations. This proved that the LEACHM model is a promising tool for nitrate management under field conditions.
Abou Arab A.A., S.A. Mohamed, M.A. Mohamed and A.M. Ibrahim. 1998. Effect of soil compaction on some soil properties under different moisture. Egypt. J. Soil Sci. 38:211-228.

Abdallah, A.M. 2008. Reduce of nitrate leaching using localized compaction and irrigation management in sandy loam soils. MSc. Thesis, Fac. Agric., Damanhour University. Egypt.

Aggag, A.M. 2001. Groundwater pollution control by improving irrigation water and fertilization management. Ph.D. thesis. Alexandria Egypt

Allen, R.G., L.S. Pereira, D. Raes and M. Smith. 1998. Crop Evapotranspiration Guidelines for Computing Crop Water Requirements. FAO, Irrigation and Drainage Paper No. 56. Rome. Italy.

Alva, A.K., S. Paramasivam, A. Fares, T.A. Obreza and A.W. Schumann. 2006. Nitrogen best management practice for citrus trees. Scientia hort. 109: 223-233.

Arnold, E.G., L.S. Clesceri and A.D. Eataon. 1992. Standard Methods for Examination of Water and Waste water $18^{\text {th }}$ ed. 4: 87-88.

Baker, J.L. 2002. Limitations of improved nitrogen management to reduce nitrate leaching and increase use efficiency. Optimizing nitrogen management in food and energy production and environmental protection. $2^{\text {nd }}$ International Nitrogen Conference. Potomac. Maryland. USA : 10-16.

Baker, J.L., J.M. Laflen and M.M. Schreiber. 1997. Potential for localized compaction to reduce leaching of injected anions. J. Environ. Qual. 26: 387-393.

Brindha, K. and L. Elango. 2014. Soil and groundwater quality with reference to nitrate in a semiarid agricultural region. Arab J. Geosci. 7: 4683-4695. DOI 10.1007/s12517-013-1100-5.

CoStat version 6.400. Copyright $(\subset$ 1998-2008 CoHort Software. 798 Lighthouse Ave. PMB 320, Monterey, CA, 93940, USA

Diez, J.A. 1997. Nitrate leaching from soils under a maizewheat-maize sequence, two irrigation schedules and three types of fertilizers. Agric, Ecosystems Environ. 65: 189199.

Ehteshami, M., A.S. Langeroudi and S. Tavassoli. 2013. Simulation of Nitrate Contamination in Groundwater Caused by Livestock Industry (Case Study: Rey). J. Environ. Protec. 4: 91-97. http://dx.doi.org/10.4236/jep.2013.47A011. 
El-Nady, M.A. 2004. The role of soil compaction on nonlimiting soil water range in some soils of Egypt. Ph.D. thesis, Cairo University Egypt.

Emir, J. 2002. Effect of tractor wheel compaction on bulk density and infiltration rate of a loamy sand soil in Saudi Arabia. Agric. Sci. 14: 24 - 33.

FAO. 1990. Fertilizer yearbook 1990. Rome.

Feng, Z.Z., Wang, X.K. and Feng, Z.W. (2005) Soil N and salinity leaching after the autumn irrigation and its impact on groundwater in Hetao irrigation district, China. Agric.Water Manag. 2: 131143.

Gardenas, A.I., S. Hopmans, J.W. Hanson and J. Simunek. 2005. Two dimensional modeling of nitrate leaching for various fertigation scenarios under micro-irrigation. Agric. Water Manag. 74:219242

Gehl, R.J., J.P. Schmidt, L.R. Stone, A.J. Schlegel and G.A. Clark. 2005. Measurements of nitrate leaching implicate poor nitrogen and irrigation management on sandy soils. J. Environ. Qual. 34: 2243-2254.

Gehl, R.J., J.P. Schmidt, L.R. Stone and L.D. Maddux. 2004. Quantifying nitrate leaching in sandy soils as affected by nitrogen and water management. Proceedings of Great Plains Soil Fertility Conference. pp.14-20.

Hartge, K.H., H. Bohne, H.P. Schery and H. Extra. 1985. Penetration measurements for screening soil physical variability. Soil tillage Res. 5: 343-350.

Hillel, D. and R.S. Baker. 1998. A descriptive theory of fingering during infiltration into layered soils. Soil Sci.146:51-56.

Huggins, D.R. and W.L. Pan. 1993. Nitrogen efficiency component analysis: an evaluation of cropping system differences in productivity. Argon. J. 85: 895-905

Hutson, J.L. 2003. Leaching estimation and chemistry model, Version 4, School of Chemistry, Physics and Earth Sciences. The Flinders University of South Australia. GPO Box 2100, Adelaide, SA5001.

Jabor, J.D., E.G. Lotse, D.D. Fritton and D.E. Baker. 1994. Estimation of preferential movement of bromide under field conditions. J. Hydro. 156: 61-71.

Kiuchi, M., T.C. kaspar and R. Horton. 1996. Managing soil water and chemical transport with subsurface flow barriers. Soil. Sci. Soc. Am. J. 60: 880-887

Klute, A. 1986a. Methods of Soil Analysis. Part 1, physical and mineralogical analysis methods $2^{\text {nd }}$ ed Agron. Mo. 9, Madison. Wisconsin, U.S.A.

Klute, A. 1986b. Water retention: Laboratory methods. p. 635-662. In A. Klute (Ed.). Methods of Soil Analysis. Part 1. $2^{\text {nd }}$ ed. Agron. Mo. 9. ASA and SSSA, Madison, WI.

Kucharik, C.J. and K.R. Barye. 2003. Integrated biosphere simulator (IBIS) yield and nitrate loss predictions for Wisconsin maize receiving varied amounts of nitrogen fertilizer. J. Environ. Qual. 32 (1): 247-258.

Majnooni-Heris, A. 2014. Estimation of soil water content, N$\mathrm{NO}_{3}$ and plant stover $\mathrm{N}$ uptake for Urea fertilization management. Agric. Sci. Dev. 3:(6) 222-229.
Majnooni-Heris, A., S.H. Zand-Parsa, A.S. Sepaskhah, A.A. Kamgar-Haghighi and J. Yasrebi. 2011. Modification and validation of maize simulation model (MSM) at different applied water and nitrogen levels under furrow irrigation. Arch Agron. Soil Sci. 57: 401-420.

Mooney, S.J. and W. Nipattasuk. 2003. Quantification of the effects of soil compaction on water flow using dye tracers and image analysis .Soil Use Manag. 19: 356-363.

Naoko, H., M. Yasushi and I. mitsuhiro. 2005. Management of fertilizer leaching from the root zone using an automated infiltration soil water sampler in an unsaturated sandy field. Soil Sci. Plant Nutirit. 51: 1023-1033.

Nasri, N., M. Chebil, L. Guellouz, R. Bouhlila, A. Maslouhi and M. Ibnoussina. 2015. Modelling nonpoint source pollution by nitrateof soil in the Mateur plain, northeast of Tunisia. Arab J. Geosci. 8:1057-1075.

Nassar, I.N. and R. Horton. 1997. Heat, water, and solute transfer in unsaturated soil: I- Theory development and transport coefficient evaluation. Transport in Porous Media. 27: 1738.

Pathak, H., U.K. Singh, A.K. Patra and N. Kalra. 2004. Fertilizer use efficiency to improve environmental quality. Fertilizers news. 49: 101-110.

Peack, K. and M.V. Tracey. 1956. Modern Methods of Plant Analysis. 1: 645-652.

Peng, X.H., R. Horn, B. Zhang and Q.G. Zhao. 2004. Mechanisms of soil vulnerability to compaction of homogenized and recomputed Ultisols .Soil and Tillage Res. 76: 125-137.

Ressler D.E., R. Horton, J.L. Baker and T. Kaspar. 1998-a. Evaluation of localized compaction and doming to reduce anion leaching losses using lysimeters. J. Environ. Qual. 27: 910-916.

Ressler, D.E., R. Horton, J.L. Baker and T.C. Kaspar. 1997. Testing a nitrogen fertilizer applicator designed to reduce leaching losses. Applied Engin. Agric. 13: 345-350.

Ressler, D.E., R. Horton, T.C. Kaspar and J.L. Baker. 1998-b. Localized soil management in fertilizer injection zone to reduce nitrate leaching. Agron. J. 90: 747-752.

Schneider, A.D. and T.A. Howell. 1999. LEPA and spray irrigation for grain crops. J. Irrig. Drain. Engin.125: 167172.

Seo, Y., J. Lee, W.E. Hart, H.P. Denton, D.C. Yoder, E. Essington and E. Perfect. 2005. Sediment loss and nutrient runoff from three fertilizer application methods. Am. Soc. Agric. Engin. J. 48: 21552162.

Sumanasena, H.A., D.J. Horn, D.R. Scotter and P.D. Kemp. 2004. The effect of irrigation scheduling on nitrogen and phosphorus leaching under Pasteure. Tropic. Agric. Research. 16: 193-203.

Tani, M., T. Okuten, M. Koike, K. Kuramochi and R. Kondo. 2004. Nitrate adsorption in some Andisols developed under different moisture conditions. Soil Sci. Plant Nutrit. 50: 439-446. 
Wagenet, R.J. and J.L. Hutson. 1989. LEACHM: Leaching Estimation and Chemistry Model: A process based model of water and solute movement transformation, plant uptake and chemical reactions in the unsaturated zone. Continuum Vol. 2. Water Resources Inst., Cornell University, Ithaca, NY.

Xevi E., J. Gilley and J. Feyen. 1996. Comparative study of two crop yield simulation models. Agric. Water Manag. 30(2): $155-174$
Zand-Parsa, Sh., A.R. Sepaskhah and A. Rownaghi. 2006. Development and evaluation of integrated water and nitrogen model for maize. Agric. Water Manag. 81: 227256.

Zhao, B.Q., X.Y. Li, H. Liub, B.R. Wanga, P. Zhuc, S.M. Huangd, D.J. Baod, Y.T. Li and H.B. So. 2011. Results from long-term fertilizer experiments in China: The risk of groundwater pollution by nitrate. NJAS - Wageningen J. Life Sci. 58: 177- 183.

\section{الملخص العرب}

مصير النترات في جظل ذرة نامية تنه نماذج مختلفةمن الرجيم المائ والضطظ الموضصي

$$
\text { لحمد محمد عجاج }
$$

ووزن الكوز وطول الكوز وظطر الكوز ومسلحة سطح الورقة وطول النبت وقطر السلق ووزن الورقة الرطب

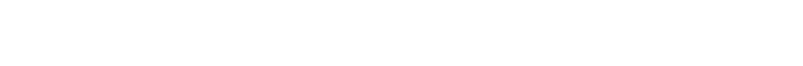

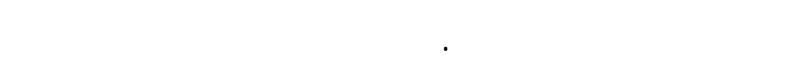
الزئيد من النترات بالغسل في معالملة الري II-2. النترات

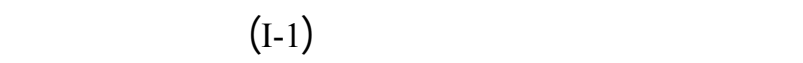
 بالغسل لمعلملات الضغط الموضعى الأربعة تهمت معلملة

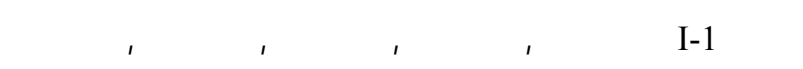

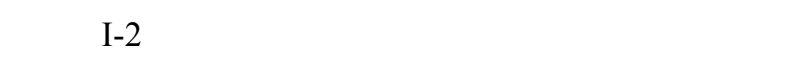
IVV,V7

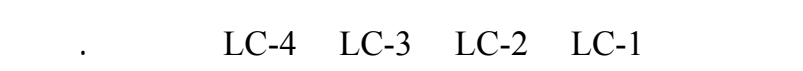

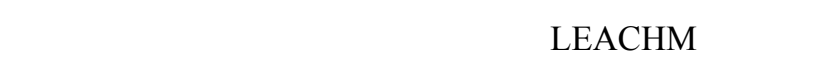
وكذك النترات المفقوة بالغسل بالمقارنة مع القيم المقلسة. قدرة الموديل على التنبؤ بالنترات قيمت بلستخدلم مقاييس النبل

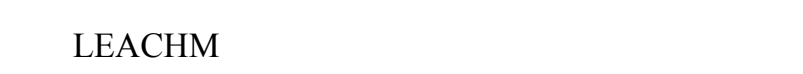

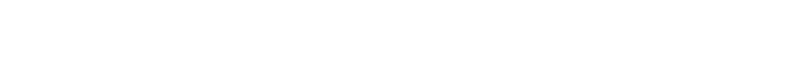
في مزارع الذرة تمتظطروف التجربة المنكورة.
الهف من هذه الدرلسة هو ققيم الضط الموضعي

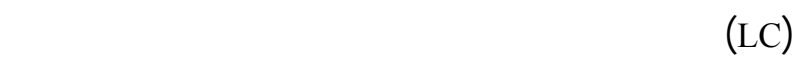
المزروعة في أرض جيرية وفقد النترات بالغسل وأيضا النال وققييم موديل LEACHM في التبؤ بالميل والنترات مكانياً وزمانياً في التربة. لجريت تجربة هقلية في أرض جيرية النيرية

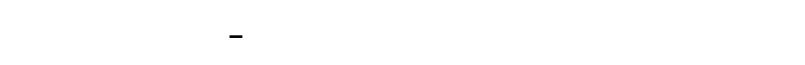

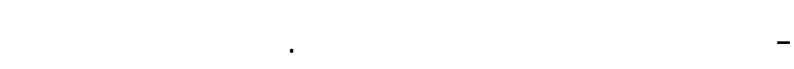

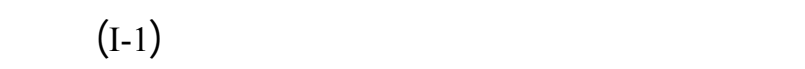

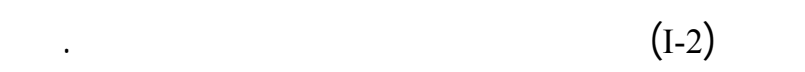

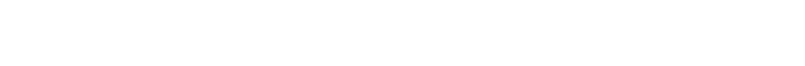

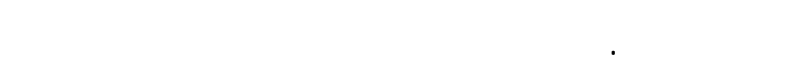

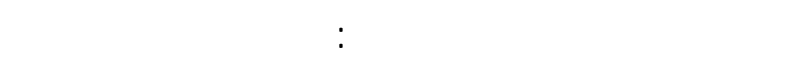

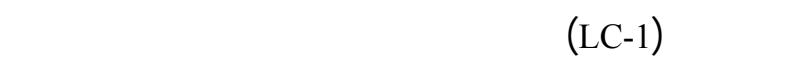

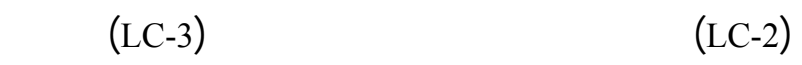

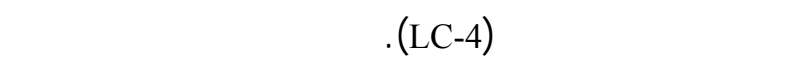

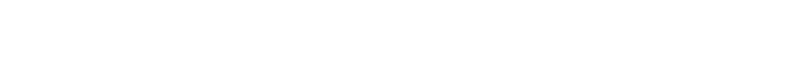

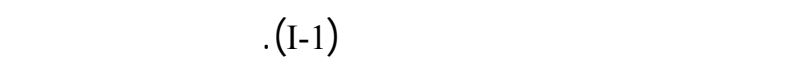

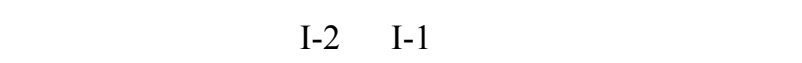

